Article

\title{
Citric Acid Influences the Dynamics of the Fermentation Quality, Protease Activity and Microbial Community of Mulberry Leaf Silage
}

\author{
Dekui Chen ${ }^{\dagger}$, Wei Zhou ${ }^{\dagger}$, Xiang Guo $\mathbb{D}$, Mingyang Zheng, Xiaoyang Chen * and Qing Zhang * \\ Guangdong Province Research Center of Woody Forage Engineering Technology, South China Agricultural \\ University, Guangzhou 510642, China; chendekui1996@stu.scau.edu.cn (D.C.); wzhou@scau.edu.cn (W.Z.); \\ 7090gx@stu.scau.edu.cn (X.G.); zmysndd@stu.scau.edu.cn (M.Z.) \\ * Correspondence: xychen@scau.edu.cn (X.C.); zqing@scau.edu.cn (Q.Z.) \\ + These authors contribute equally to this work.
}

\section{check for} updates

Citation: Chen, D.; Zhou, W.; Guo, X.; Zheng, M.; Chen, X.; Zhang, Q. Citric Acid Influences the Dynamics of the Fermentation Quality, Protease Activity and Microbial Community of Mulberry Leaf Silage. Fermentation 2021, 7, 185. https://doi.org/ $10.3390 /$ fermentation7030185

Academic Editors:

Clemencia Chaves-López and Annalisa Serio

Received: 18 August 2021 Accepted: 7 September 2021 Published: 9 September 2021

Publisher's Note: MDPI stays neutral with regard to jurisdictional claims in published maps and institutional affiliations.

Copyright: (c) 2021 by the authors. Licensee MDPI, Basel, Switzerland. This article is an open access article distributed under the terms and conditions of the Creative Commons Attribution (CC BY) license (https:/ / creativecommons.org/licenses/by/ $4.0 /)$.

\begin{abstract}
Mulberry (Morus alba) leaves has performed well as a high-quality protein supplement for livestock and enriches the edible resources of livestock. However, the harvest of mulberry leaves is seasonal and occurs mainly during the rainy season in southeast China; therefore, humid and sultry weather causes serious losses of mulberry leaf biomass, which pose a challenge for the preservation of mulberry leaves. In this study, we used the silage fermentation method to preserve mulberry leaves and investigated the effects of citric acid on the silage quality of mulberry leaves. Mulberry leaves were ensiled with or without $1 \%$ citric acid and $2 \%$ citric acid. The chemical composition, protein fraction and microbial community of mulberry leaf silages were analyzed. The results showed that the silage treated with citric acid had a higher dry matter recovery and lactic acid content and a lower acetic acid content, non-protein nitrogen content and ammonia- $\mathrm{N}$ content; citric acid also inhibited the activities of carboxypeptidase and aminopeptidase. Moreover, citric acid increased Lactobacillus abundance in silages and decreased the abundance of undesired microorganisms, such as Enterobacter. In summary, the addition of citric acid improved the fermentation quality of mulberry leaf silages, with $2 \%$ citric acid being more effective than $1 \%$ citric acid.
\end{abstract}

Keywords: mulberry leaves; silage; citric acid; fermentation quality

\section{Introduction}

Mulberry (Morus alba) is a traditional, economical woody plant and is cultivated across more than 780,000 ha in China [1]. The biomass yield of fresh mulberry leaves (ML) ranges from 25 to $30 \mathrm{mt} / \mathrm{ha} / \mathrm{yr}$ [2]. The crude protein of ML ranges from 15 to $27.6 \%$ dry matter (DM) and ML is rich in minerals (2.42-4.71\% Ca, 0.23-0.97\% $\mathrm{P}, 1.66-3.25 \% \mathrm{~K})$ [3]. As it is rich in nutrients, ML has performed well as a high-quality protein supplement for livestock [4]. In addition, ML has many biological benefits because it has antioxidant, anti-inflammatory, antidiabetic and antihyperglycemic properties, etc., and thus could potentially replace antibiotics to improve animal immunity $[5,6]$. However, the harvest of ML is seasonal and occurs mainly during the rainy season in southeast China, making it difficult to dry fresh ML naturally.

Ensiling is an efficient, low-cost and suitable method of preserving ML quality which can overcome the seasonal imbalance between forage resources and animal production. In a previous study, it was observed that proteolysis was a very serious problem in ML silage [7]. It is known that the activities of plant enzymes and microorganisms are mainly responsible for proteolysis, which can degrade proteins into peptides and further into ammonia-N [8]. However, information regarding the dynamics of proteolysis and the activities of protease and microorganisms in ML silage is lacking. Evaluation of the proteolytic mechanism would be beneficial in providing a theoretical basis for finding suitable proteolytic inhibitors of ML silage. 
Citric acid (CA) is an organic acid with a higher pKa than lactic acid, which could directly acidize the fermentation environment $[9,10]$. CA is easy to obtain by microorganism fermentation. With a pleasant, tart flavor and low cost, CA is widely used in the food and beverage industries and as a complement in animal feed [11]. Compared with formic acid and sulfuric acid, CA might be a milder acidic additive in silage [12]. In previous studies, the addition of CA improved the quality of alfalfa silage and decreased Clostridium and Escherichia abundance in Amomum villosum Lour silages [13,14]. However, little information about CA's influence on the protein fractions and protease activities of silages is available.

Therefore, the goal of this study was to investigate the effect of CA on the fermentation parameters, protein, protease activities and bacterial community of ML silage.

\section{Materials and Methods}

\subsection{Pre-Ensiled Material and Silage Preparation}

ML was cultivated and harvested from an experiment field in December 2020 at South China Agricultural University (Guangzhou, China, $113^{\circ} 35^{\prime}$ E, $23^{\circ} 16^{\prime} \mathrm{N}$ ). CA was purchased from Sinopharm Chemical Reagent Co. Ltd. (Shanghai, China). The ML was immediately chopped to a suitable length $(1-2 \mathrm{~cm})$ in a clean test bed when it was harvested. The ML was then ensiled with $1 \%$ or $2 \%$ CA. A control group (CK) involved no addition of CA. In detail, approximately $100 \mathrm{~g}$ ML was ensiled in an enclosed bag $(20 \mathrm{~cm} \times 30 \mathrm{~cm})$ in triplicate for every treatment. In total, 36 sealed silage bags ( 3 treatments $\times 4$ ensiling times $\times 3$ repeats) were made and kept at ambient temperature $\left(17-28^{\circ} \mathrm{C}\right)$. After $3,7,14$ and 30 days of ensiling, to evaluate the fermentation parameters, protease activity and the bacterial community, three silage bags from each treatment were opened at random.

\subsection{Microorganism and Fermentation Parameter Analyses}

We used the flat colony counting method to count the microbial population of silages according to Yan et al. [15]. A sample (10 g) from each silage bag and sterilized saline water $(90 \mathrm{~mL})$ were homogenized in a blender and then serially diluted. The population of lactic acid bacteria was counted in Man Rogosa Sharpe agar and that of coliform bacteria was counted in Violet Red Bile agar, and samples were subsequently incubated at $30{ }^{\circ} \mathrm{C}$ for $48 \mathrm{~h}$. Molds and yeasts were cultured and counted in Rose Bengal agar at $28^{\circ} \mathrm{C}$ for $48 \mathrm{~h}$ and then categorized by colony morphology. All microbial population counts were log 10 transformed.

Another sample (10 g) from each silage bag was diluted in sterile distilled water $(90 \mathrm{~mL})$ and stored in a freezer at $4{ }^{\circ} \mathrm{C}$ for $18 \mathrm{~h}$, then the homogenized sample was filtered. Part of the filtrate was immediately used to measure $\mathrm{pH}$, and the remaining filtrate was used to measure the ammonia-N content and organic acid content. Following Broderick and Kang [16], the phenol-hypochlorite procedure was used to measure the ammonia-N content. The concentration of organic acids was measured using high-performance liquid chromatography (HPLC) (column, Shodex RSpak KC-811S-DVB gel C $(8.0 \mathrm{~mm} \times 30 \mathrm{~cm}$; Shimadzu, Tokyo, Japan); oven temperature, $50{ }^{\circ} \mathrm{C}$; mobile phase, $3 \mathrm{mmol} / \mathrm{L} \mathrm{HClO}_{4}$; flow rate, $1.0 \mathrm{~mL} / \mathrm{min}$; injection volume, $5 \mu \mathrm{L}$; detector, SPD-M10AVP) [17].

An oven was used to dry the remaining silage at $65{ }^{\circ} \mathrm{C}$ for $48 \mathrm{~h}$ for measurement of the DM content. For chemical analysis, these dry samples were ground with a grinder (FW100, Taisite Instrument Co., Ltd., Tianjin, China) and passed through a $1.00 \mathrm{~mm}$ screen. The powder samples were used to measure protein, fiber and water-soluble carbohydrates. The content of protein fractions, neutral detergent fiber and acid detergent fiber were determined by the method of Wang et al. [2]. Briefly, crude protein and true protein were analyzed using the Kjeldahl nitrogen analyzer (Kjeltec 2300 Auto-Analyzer, FOSS Analytical AB, Hoganas, Sweden). Non-protein nitrogen was calculated from the difference between crude and true protein. Neutral detergent fiber (NDF) and acid detergent fiber content were measured without use of heat-stable amylase and sodium sulfite in an A220 Fiber Analyzer (ANKOM Technology Corp., Macedon, NY, USA). The water-soluble carbohydrate content was analyzed by the anthrone method. 


\subsection{Protease Activity Analysis}

The protease was extracted according to the method of He et al. [8], with some modifications. A sample $(10 \mathrm{~g})$ from the silage bag and a $0.1 \mathrm{M}$ sodium phosphate buffer $(50 \mathrm{~mL}$, $\mathrm{pH} 6.0$ with $5 \mathrm{mM}$ hyposulfite) were homogenized in a blender, then the homogenate was filtered and the filtrate was centrifuged at $10,000 \times g$ at $4{ }^{\circ} \mathrm{C}$ for $15 \mathrm{~min}$. The supernatant was retained at $-80{ }^{\circ} \mathrm{C}$ for later use. According to the method of Guo et al. [18], acid protease activity, carboxypeptidase activity and aminopeptidase activity were measured.

\subsection{Analysis of Microbial Communities}

Following the manufacturer's instructions, microbial DNA was extracted by the HiPure Stool DNA Kits (Magen, Guangzhou, China). The primers 341F (ACTCCTACGGGAGGCAGCAG) and 806R (GGACTACHVGGGTWTCTAAT) were used for amplifying $16 \mathrm{~S}$ rDNA V3-V4 in a PCR thermal cycler (FlexCycler; Analytik Jena, Jena, Germany). DNA was amplified according to the procedure of Zhang et al. [19]. Illumina NovaSeq 6000 was used to sequence the purified PCR products. The raw reads were assembled according to the procedure set by Liu et al. [20].

\subsection{Statistical Analysis}

The analyses of the fermentation parameters were performed with SAS version 9.1 (SAS Institute, Cary, NC, USA) to evaluate the influence of treatment and ensiling time. Duncan's multiple range tests were used to measure mean values. $p<0.05$ was considered significant and $p<0.01$ was considered extremely significant. In addition, Pearson's correlation analysis between protein fractions and protease activity was conducted with SAS.

\section{Results and Discussion}

\subsection{Characteristics of Pre-Ensiled ML}

The characteristics of the pre-ensiled ML are shown in Table 1. The DM content of ML was $374 \mathrm{~g} / \mathrm{kg}$ fresh matter (FM). The relatively high DM content of ML is comparable with that of tropical legumes, such as alfalfa and stylo [21]. The crude protein content of ML was $139 \mathrm{~g} / \mathrm{kg}$ DM. It was lower than the $188 \mathrm{~g} / \mathrm{kg}$ DM reported by Wang et al. [2]; this might be because it was at the mature stage [22]. Neutral detergent fiber is an inferior predictor of digestibility [7]. The low neutral detergent fiber content $(440 \mathrm{~g} / \mathrm{kg} \mathrm{DM})$ indicated that ML probably had better digestive efficiency as a fodder for animals. The water-soluble carbohydrates were a necessary fermentation substrate during the ensiling process and its content of greater than $60 \mathrm{~g} / \mathrm{kg}$ DM was a guarantee of thorough fermentation [19]. Water-soluble carbohydrate content was $114 \mathrm{~g} / \mathrm{kg}$ DM in this study, which was enough to support the acid production efficiency of microorganisms. Epiphytic lactic acid bacteria and coliform bacteria counts were $5.72 \log 10 \mathrm{cfu} / \mathrm{g}$ FM and $5.21 \log 10 \mathrm{cfu} / \mathrm{g}$ FM, respectively. Yeasts and molds were below detectable levels (2.00 log $10 \mathrm{cfu} / \mathrm{g}$ FM). During the ensiling, lactic acid bacteria counts of more than $5.00 \log 10 \mathrm{cfu} / \mathrm{g}$ FM are considered to be a superior predictor of fermentation quality [23]. However, the relatively high coliform bacteria counts might result in poor fermentation, which suggests that fermentation inhibitors were necessary to inhibit undesirable microorganisms.

Table 1. The chemical composition and microbial population of pre-ensiled mulberry leaves.

\begin{tabular}{cc}
\hline Items & Mulberry Leaves \pm SEM \\
\hline Dry matter (g/kg FM) & $374 \pm 12.8$ \\
Crude protein (g/kg DM) & $139 \pm 1.9$ \\
Neutral detergent fiber (g/kg DM) & $440 \pm 35.7$ \\
Acid detergent fiber (g/kg DM) & $353 \pm 24.8$ \\
Water soluble carbohydrates (g/kg DM) & $114 \pm 3.2$ \\
Lactic acid bacteria $\left(\log _{10} \mathrm{cfu} / \mathrm{g} \mathrm{FM}\right)$ & $5.72 \pm 0.1$ \\
Coliform bacteria $\left(\log _{10} \mathrm{cfu} / \mathrm{g} \mathrm{FM}\right)$ & $5.21 \pm 0.3$ \\
\hline
\end{tabular}


Table 1. Cont.

\begin{tabular}{cc}
\hline Items & Mulberry Leaves \pm SEM \\
\hline Yeasts $\left(\log _{10} \mathrm{cfu} / \mathrm{g}\right.$ FM) & $<2.00$ \\
Molds $\left(\log _{10} \mathrm{cfu} / \mathrm{g}\right.$ FM) & $<2.00$ \\
\hline
\end{tabular}

FM, fresh material; DM, dry matter; SEM, standard error of the mean; cfu, colony-forming unit.

\subsection{The Fermentation Parameters, Organic Acids and Microbial Population of ML Silages}

DM recovery, the dynamics of the $\mathrm{pH}$ value, organic acid content and microbial population counts in ML silages are shown in Figure 1. The factor analysis revealed that CA had a significant effect $(p<0.01)$ on DM recovery, $\mathrm{pH}$, lactic acid content, acetic acid content, lactic acid bacteria counts and coliform bacteria counts in ML silages. DM loss is a common issue during every stage of ensiling, which reduces the silage yield [24]. The silages treated with CA showed higher DM recovery than the $\mathrm{CK}$, and the highest DM recovery occurred in the silages treated with $2 \% \mathrm{CA}$ after 30 days of ensiling. The increase in DM recovery would significantly improve the economic efficiency of ML as an excellent protein supplement for livestock. The $\mathrm{pH}$ is the most intuitive fermentation parameter, which directly reflects the quality of silage. The $\mathrm{pH}$ value of silages treated with $\mathrm{CA}$ was lower than that of the CK during the ensiling process in this study. The $\mathrm{pH}$ value of ML silages reached stability in 3 days of ensiling, and the final $\mathrm{pH}$ was lower than 4.5 with the addition of $2 \% \mathrm{CA}$. It might be that enough CA directly reduced the $\mathrm{pH}$ value due to its strong acidity, with a pK1 3.13 [10]. However, the $\mathrm{pH}$ value of silage treated with $1 \% \mathrm{CA}$ was maintained at around 5.0 and the final $\mathrm{pH}$ value of the CK remained approximately 6.0, which might be due to the high buffer capacity of ML [25]. The relatively low $\mathrm{pH}$ of ML silage ensiled with CA indicated that CA could effectively promote the fermentation of ML.

During the ensiling process, lactic acid and acetic acid were the dominant organic acids in ML silage, and no butyric acid or propionic acid was detected. The addition of CA significantly increased $(p<0.01)$ the lactic acid content and reduced the acetic acid content of ML silages. Similarly, Ke et al. [14] reported that $0.1 \%$ CA and $0.5 \%$ CA increased the lactic acid content. In the first 7 days of ensiling, the lactic acid accumulated rapidly in the ML silages. After 7 days of ensiling, the lactic acid content decreased in the silages treated with $2 \% \mathrm{CA}$, and after 14 days of ensiling in the CK and the silages treated with $1 \% \mathrm{CA}$. At the same time, the acetic acid content of the CK and the silages treated with $1 \% \mathrm{CA}$ increased. The drop in lactic acid content and the rise in acetic acid content indicated that part of the lactic acid was converted into acetic acid, which might be caused by heterofermentation of the lactic acid bacteria, such as Lactobacillus buchneri [26]. Moreover, the ML silages treated with CA showed a lower $(p<0.01)$ ratio of acetic acid to lactic acid than the CK, which suggested that the addition of CA promoted the accumulation of lactic acid and inhibited the production of acetic acid during the ensiling process.

The dynamics of lactic acid bacteria, coliform bacteria and yeasts are shown in Figure 1. In the first 7 days of ensiling, lactic acid bacteria counts increased rapidly, which could explain the accumulation of lactic acid at the same time. The lactic acid bacteria counts then decreased from $8.0 \log 10 \mathrm{cfu} / \mathrm{g}$ FM to $6.0 \log 10 \mathrm{cfu} / \mathrm{g}$ FM when the ensiling time was prolonged, which was consistent with the report by Wang et al. [2]. The reduction in lactic acid bacteria counts might be explained by the lack of water-soluble carbohydrates as a fermentation substrate [27]. Compared with the CK, lower $(p<0.01)$ coliform bacteria counts were observed in the silages treated with CA during the ensiling process, which could explain the higher DM recovery and the lower acetic acid content in these silages. Moreover, the reduction in coliform bacteria counts of silages treated with CA was consistent with those reported by Mohan and Pohlman [28].

When the ensiling time was prolonged, yeast counts decreased $(p<0.01)$, which might be because the progressively anoxic situation inhibited its growth. Unexpectedly, no yeast was detected in the silages treated with $2 \%$ CA during the fermentation process. However, $\mathrm{Lv}$ et al. [13] reported that yeast counts were increased in alfalfa and Amomum villosum Lour silages with the addition of CA. This discrepancy was probably due to the water-soluble 
substances of the ML having a broad spectrum of antimicrobial activity [29]. Moreover, $\mathrm{CA}$ and the water-soluble substances of ML might have synergistic effects that inhibit the growth of yeasts. Therefore, these results indicated that more research is needed into the function of CA in controlling fungal growth in ML silage.

CK
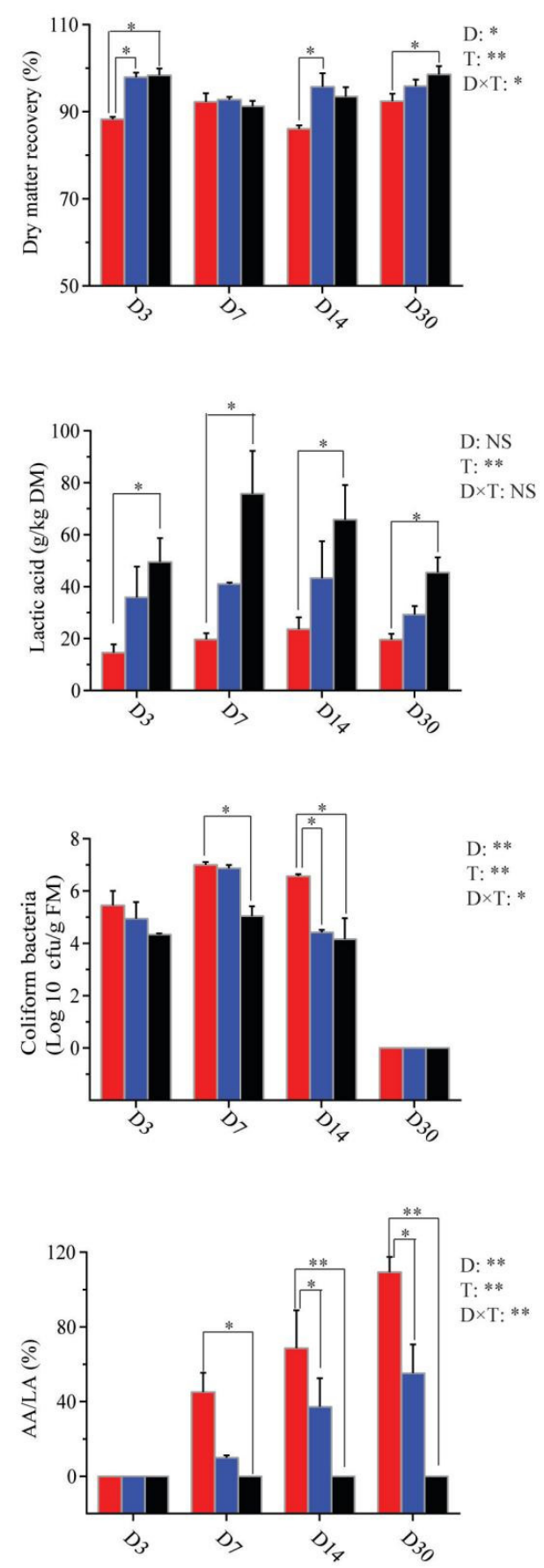

CA1
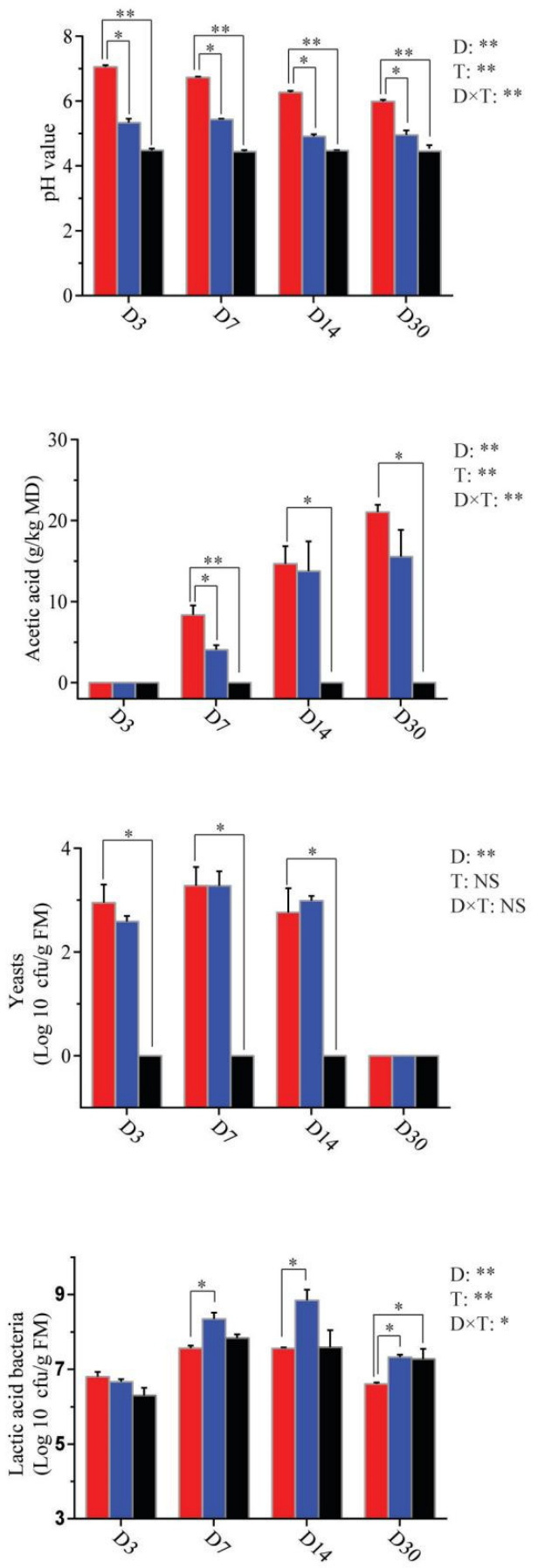

Figure 1. The fermentation parameters and microbial counts of mulberry leaf silages $(\mathrm{D}$, ensiling days; $\mathrm{T}$, treatments; $\mathrm{D} \times \mathrm{T}$, the interaction of ensiling days and treatments; ${ }^{*}, p<0.05 ;{ }^{* *}, p<0.01$; NS, non-significance; CK, the control; CA1, $1 \%$ citric acid; CA2, 2\% citric acid; D3, 3 days of ensiling; D7, 7 days of ensiling; D14, 14 days of ensiling; D30, 30 days of ensiling; $\mathrm{AA} / \mathrm{LA}$, the ratio of acetic acid to lactic acid; cfu, colony-forming units; FM, pre-ensiled material). 


\subsection{The Protein Fraction of $M l$ Silages}

The dynamics of the protein fractions of ML silages are shown in Table 2. Proteolysis is a common phenomenon in silage and is the main factor affecting the protein quality of silage [7]. In the first stage, under the action of plant proteolytic enzymes, most of the proteins are degraded into non-protein nitrogen, such as free amino acids, oligopeptides and dipeptides, then these hydrolysis products are further converted to ammonia-N by microorganism activities [7]. When the ensiling time was prolonged, the content of nonprotein nitrogen increased $(p<0.01)$ from $122 \mathrm{~g} / \mathrm{kg}$ TN to $380 \mathrm{~g} / \mathrm{kg} \mathrm{TN}$, which indicated extensive proteolysis in the ML silage. The increase in non-protein nitrogen indicated a decline in the nutritional value of silage proteins, considering that the utilization efficiency of non-protein nitrogen in ruminants is lower than that of true protein [30]. Thus, inhibitors, which could inhibit protease and microbial activities, were necessary. After 30 days of ensiling, the highest non-protein nitrogen content was observed in the CK, whereas $2 \% \mathrm{CA}$ decreased $(p<0.05)$ non-protein nitrogen content. Similarly, the addition of CA in alfalfa silages showed a quite different non-protein nitrogen content which decreased with the addition of $0.5 \%$ CA after 60 days of ensiling [31]. Moreover, compared with the CK, the non-protein nitrogen content varied less and had a lower content ( $310 \mathrm{vs.} 380 \mathrm{~g} / \mathrm{kg} \mathrm{DM}$ ) in the silages treated with $2 \% \mathrm{CA}$, implying that the proteins could be preserved better and more stably in silages treated with $2 \%$ CA.

Table 2. The protein fractions of mulberry leaf silages.

\begin{tabular}{|c|c|c|c|c|c|c|c|c|c|}
\hline \multirow{2}{*}{ Item } & \multirow{2}{*}{ Treatments } & \multicolumn{4}{|c|}{ Ensiling Days } & \multirow{2}{*}{ SEM } & \multicolumn{3}{|c|}{$p$-Value } \\
\hline & & 3 & 7 & 14 & 30 & & D & $\mathbf{T}$ & $\mathbf{D} \times \mathbf{T}$ \\
\hline \multirow{3}{*}{$\begin{array}{l}\text { Crude protein } \\
(\mathrm{g} / \mathrm{kg} \mathrm{DM})\end{array}$} & CK & $134^{\mathrm{A}, \mathrm{b}}$ & $147^{\mathrm{A}, \mathrm{a}}$ & $154^{\mathrm{A}, \mathrm{a}}$ & $153^{\mathrm{A}, \mathrm{a}}$ & \multirow{3}{*}{8.57} & \multirow{3}{*}{0.000} & \multirow{3}{*}{0.000} & \multirow{3}{*}{0.011} \\
\hline & CA1 & $136^{\mathrm{A}, \mathrm{a}}$ & $138^{\mathrm{A}, \mathrm{B}, \mathrm{a}}$ & $137^{\mathrm{B}, \mathrm{a}}$ & $146^{\mathrm{A}, \mathrm{B}, \mathrm{a}}$ & & & & \\
\hline & CA2 & $133^{A, b, c}$ & $130^{\mathrm{B}, \mathrm{c}}$ & $143^{\mathrm{B}, \mathrm{a}}$ & $139^{\mathrm{B}, \mathrm{a}, \mathrm{b}}$ & & & & \\
\hline \multirow{3}{*}{$\begin{array}{l}\text { True protein } \\
(\mathrm{g} / \mathrm{kg} \mathrm{TN})\end{array}$} & CK & $878^{\mathrm{A}, \mathrm{a}}$ & 792 A,b & $679^{B, c}$ & $620^{B, d}$ & \multirow{3}{*}{80.1} & \multirow{3}{*}{0.000} & \multirow{3}{*}{0.679} & \multirow{3}{*}{0.000} \\
\hline & CA1 & $816^{\mathrm{B}, \mathrm{a}}$ & $748^{\mathrm{B}, \mathrm{b}}$ & $752^{\mathrm{A}, \mathrm{b}}$ & $625^{\mathrm{A}, \mathrm{B}, \mathrm{c}}$ & & & & \\
\hline & CA2 & $808^{\mathrm{B}, \mathrm{a}}$ & $764^{\mathrm{A}, \mathrm{B}, \mathrm{b}}$ & $678^{\mathrm{B}, \mathrm{c}}$ & $690^{\mathrm{A}, \mathrm{c}}$ & & & & \\
\hline \multirow{3}{*}{$\begin{array}{l}\text { Non-protein } \\
\text { nitrogen } \\
(\mathrm{g} / \mathrm{kg} \mathrm{TN})\end{array}$} & CK & $122^{\mathrm{B}, \mathrm{d}}$ & $208^{B, c}$ & $321^{\mathrm{A}, \mathrm{b}}$ & $380^{\mathrm{A}, \mathrm{a}}$ & \multirow{3}{*}{80.1} & \multirow{3}{*}{0.000} & \multirow{3}{*}{0.679} & \multirow{3}{*}{0.000} \\
\hline & CA1 & $184^{\mathrm{A}, \mathrm{c}}$ & $252^{A, b}$ & $248^{\mathrm{B}, \mathrm{b}}$ & $375^{\mathrm{A}, \mathrm{B}, \mathrm{a}}$ & & & & \\
\hline & CA2 & $196^{\mathrm{A}, \mathrm{c}}$ & $236^{\mathrm{A}, \mathrm{b}}$ & $322^{\mathrm{A}, \mathrm{a}}$ & $310^{\mathrm{B}, \mathrm{a}}$ & & & & \\
\hline \multirow{3}{*}{$\begin{array}{c}\text { Ammonia-N } \\
(\mathrm{g} / \mathrm{kg} \mathrm{TN})\end{array}$} & $\mathrm{CK}$ & $4.40^{\mathrm{A}}$ & $7.38^{\mathrm{A}}$ & $14.6^{\mathrm{A}}$ & $18.9^{\mathrm{A}}$ & \multirow{3}{*}{5.15} & \multirow{3}{*}{0.000} & \multirow{3}{*}{0.000} & \multirow{3}{*}{0.000} \\
\hline & CA1 & $3.71^{\mathrm{B}}$ & $4.57^{\mathrm{B}}$ & $7.58^{\mathrm{B}}$ & $10.8^{\mathrm{B}}$ & & & & \\
\hline & CA2 & $1.76^{\mathrm{B}}$ & $2.45^{\mathrm{C}}$ & $3.95^{C}$ & $6.07^{C}$ & & & & \\
\hline
\end{tabular}

$\mathrm{D}$, ensiling days; T, treatments; $\mathrm{D} \times \mathrm{T}$, the interaction of ensiling days and treatments; $\mathrm{DM}$, dry matter; $\mathrm{CK}$, the control; CA1, $1 \%$ citric acid; CA2, 2\% citric acid; TN, total nitrogen. Different lowercase letters ${ }^{(a-c)}$ in the same row indicate significant differences at $p<0.05 ;$ different uppercase letters ${ }^{(A-C)}$ in the same column indicate significant differences at $p<0.05$.

Ammonia-N, reflecting the degree of deamination of amino acids and peptide, is a more precise index compared with non-protein nitrogen. Consistent with the nonprotein nitrogen content, the content of ammonia- $\mathrm{N}$ increased $(p<0.01)$ when the ensiling time was prolonged, which was related to the deamination of amino acids and peptides caused by microbial activities [8]. During ensiling, the content of ammonia-N decreased $(p<0.01)$ in the silages treated with CA, indicating that CA inhibited the deamination of microorganisms. This inhibition could suggest that the amount of free amino acids, oligopeptides and dipeptides in non-protein nitrogen increased with the addition of CA, thereby improving the nutritive value of non-protein nitrogen. Similarly, Ke et al. [31] observed that ammonia-N decreased from $132 \mathrm{~g} / \mathrm{kg}$ TN to $31.7 \mathrm{~g} / \mathrm{kg}$ TN with the addition of $0.5 \%$ CA.

Compared with the $\mathrm{CK}$, the relatively low content of ammonia-N in the silages treated with CA might be due to direct acidification and the antimicrobial properties of CA inhibiting the growth of undesirable microorganisms, such as Clostridium and Enterobacter, which is in accordance with the decrease in coliform bacteria counts [13]. Moreover, the 
silages treated with $2 \%$ CA showed the lowest ammonia-N content during the ensiling process. The above results indicate that CA improved the silage quality of ML.

\subsection{The Protease Activities of ML Silage}

The protease activities of ML silage are shown in Table 3. Carboxypeptidase, aminopeptidase and acid protease were the exopeptidases mainly responsible for the first stages of proteolysis [8]. Carboxypeptidase activity increased $(p<0.01)$ when the ensiling time was prolonged. The increased activity of carboxypeptidase may be related to the decrease in $\mathrm{pH}$ towards 5.4, at which point carboxypeptidase was optimally active [32]. However, carboxypeptidase activity remained stable in the silage treated with $2 \%$ CA during the ensiling process. However, carboxypeptidase activity was consistently higher than 60.0 units/h/DM at 30 days of ensiling in all treatments, which could partly account for the relatively high non-protein nitrogen content of ML silage (Table 2). Aminopeptidase had low tolerance to $\mathrm{pH}$ and the optimal activity of aminopeptidase was observed at $\mathrm{pH} 7.0$ [18]. Aminopeptidase activity gradually decreased $(p<0.01)$ in this study, which was consistent with the change in $\mathrm{pH}$ value (Figure 1 ). Moreover, aminopeptidase activity sharply decreased $(p<0.01)$ with the addition of CA, which might be due to the direct acidification of CA. Similarly, Yuan et al. [32] and He et al. [8] observed that formic acid decreased aminopeptidase activity by rapid acidification of the silage. Furthermore, aminopeptidase can release free amino acid residues to provide an additional easily assimilated carbon source for lactic acid bacteria via deamination, accumulating extracellular ammonia-N [8] Thus, the CA-inhibited aminopeptidase activity might partially account for the decrease in ammonia-N (Table 2).

Table 3. The protease activities of mulberry leaf silages.

\begin{tabular}{|c|c|c|c|c|c|c|c|c|c|}
\hline \multirow{2}{*}{ Item } & \multirow{2}{*}{ Treatments } & \multicolumn{4}{|c|}{ Ensiling Days } & \multirow{2}{*}{ SEM } & \multicolumn{3}{|c|}{$p$-Value } \\
\hline & & 3 & 7 & 14 & 30 & & D & $\mathbf{T}$ & $\mathbf{D} \times \mathbf{T}$ \\
\hline \multirow{3}{*}{$\begin{array}{l}\text { Carboxypeptidase } \\
\text { (units/h/DM) }\end{array}$} & CK & $70.9^{A, b}$ & $66.9^{\mathrm{A}, \mathrm{b}}$ & $80.8^{\mathrm{A}, \mathrm{a}}$ & $83.1^{\mathrm{A}, \mathrm{a}}$ & \multirow{3}{*}{7.33} & \multirow{3}{*}{0.003} & \multirow{3}{*}{0.000} & \multirow{3}{*}{0.021} \\
\hline & CA1 & $69.2^{\mathrm{A}, \mathrm{a}}$ & $74.8^{\mathrm{B}, \mathrm{a}}$ & $76.5^{\mathrm{A}, \mathrm{a}}$ & $80.8^{\mathrm{A}, \mathrm{a}}$ & & & & \\
\hline & CA2 & $66.9^{\mathrm{A}, \mathrm{a}}$ & $66.9^{\mathrm{A}, \mathrm{a}}$ & $66.2^{\mathrm{B}, \mathrm{a}}$ & $65.9 \mathrm{~B}, \mathrm{a}$ & & & & \\
\hline \multirow{3}{*}{$\begin{array}{l}\text { Aminopeptidase } \\
\text { (units/h/DM) }\end{array}$} & CK & $86.5^{\mathrm{A}, \mathrm{a}}$ & $83.4^{\mathrm{A}, \mathrm{a}}$ & $23.9^{\mathrm{A}, \mathrm{b}}$ & $17.4^{\mathrm{A}, \mathrm{b}}$ & \multirow{3}{*}{28.2} & \multirow{3}{*}{0.000} & \multirow{3}{*}{0.000} & \multirow{3}{*}{0.000} \\
\hline & CA1 & $59.6^{\mathrm{B}, \mathrm{a}}$ & $65.0^{\mathrm{A}, \mathrm{a}}$ & $18.8^{\mathrm{A}, \mathrm{B}, \mathrm{b}}$ & $14.7^{\mathrm{A}, \mathrm{b}}$ & & & & \\
\hline & CA2 & $23.6^{C, a}$ & $17.7^{\mathrm{B}, \mathrm{a}, \mathrm{b}}$ & $14.75^{\mathrm{C}, \mathrm{b}}$ & $13.5^{\mathrm{A}, \mathrm{b}}$ & & & & \\
\hline \multirow{3}{*}{$\begin{array}{l}\text { Acid protease } \\
\text { (units/h/DM) }\end{array}$} & CK & $51.3^{\mathrm{A}, \mathrm{a}}$ & $47.1^{\mathrm{B}, \mathrm{a}}$ & $50.5^{\mathrm{A}, \mathrm{a}}$ & $36.6^{\mathrm{A}, \mathrm{b}}$ & \multirow{3}{*}{6.76} & \multirow{3}{*}{0.000} & \multirow{3}{*}{0.018} & \multirow{3}{*}{0.360} \\
\hline & CA1 & $55.2^{\mathrm{A}, \mathrm{a}}$ & $53.9^{\mathrm{A}, \mathrm{a}}$ & $53.5^{\mathrm{A}, \mathrm{a}}$ & $41.3^{\mathrm{A}, \mathrm{b}}$ & & & & \\
\hline & CA2 & $49.7^{\mathrm{A}, \mathrm{a}, \mathrm{b}}$ & $55.2^{\mathrm{A}, \mathrm{a}}$ & $54.4^{\mathrm{A}, \mathrm{a}, \mathrm{b}}$ & $45.8^{\mathrm{A}, \mathrm{b}}$ & & & & \\
\hline
\end{tabular}

$\mathrm{D}$, ensiling days; T, treatments; $\mathrm{D} \times \mathrm{T}$, the interaction of ensiling days and treatments; $\mathrm{DM}$, dry matter; $\mathrm{CK}$, the control; CA1, $1 \%$ citric acid; CA2, $2 \%$ citric acid. Different lowercase letters ${ }^{(a, b)}$ in the same row indicate significant differences at $p<0.05$. Different uppercase letters ${ }^{(A-C)}$ in the same column indicate significant differences at $p<0.05$.

In contrast to carboxypeptidase and aminopeptidase, acid protease activity was slightly increased $(p<0.05)$ in the silages treated with CA during the ensiling process. Although the $\mathrm{pH}$ in the silages treated with $\mathrm{CA}$ decreased, the $\mathrm{pH}$ still approached the optimal level for acid protease (4.50 in alfalfa). Thus, CA enhanced the acid protease activity. Although acid protease activity was lower than carboxypeptidase activity, it varied from 47.1 to 55.2 units/h/DM, which also promoted the hydrolysis of proteins. Overall, the relatively high activity of carboxypeptidase and the increased activity of acid protease in the silages treated with CA suggested that more CA should be added to ML silage to adjust the $\mathrm{pH}$ below 4.5 , which might better reduce the degree of protein hydrolysis and improve the silage quality of ML.

To further study the relationship between protease and protein fractions, Pearson's correlations were conducted on the data for protein fractions and protease activity. As shown in Table 4 , carboxypeptidase activity was negatively correlated $(p<0.01)$ with true protein content but positively correlated $(p<0.01)$ with non-protein nitrogen and ammonia-N content, 
which might partly explain the proteolysis in ML silage. The results indicated that CA inhibited $(p<0.01)$ carboxypeptidase activity could effectively inhibit extensive proteolysis in ML silage during the ensiling process, with $2 \%$ CA showing the best outcome.

Table 4. Pearson's correlations between protease activities and the protein fractions of mulberry leaf silages.

\begin{tabular}{cccccc}
\hline Item & True Protein & $\begin{array}{c}\text { Non-Protein } \\
\text { Nitrogen }\end{array}$ & Ammonia-N & Carboxypeptidase & Aminopeptidase Acid Protease \\
\hline True protein & 1 & & & & \\
Non-protein & -1.00 & 1 & & & \\
nitrogen & 0.00 & 0.65 & 1 & 1 & 1 \\
Ammonia-N & -0.65 & 0.06 & 0.80 & 0.62 & 0.06 \\
Carboxypeptidase & -0.06 & 0.81 & $<0.01$ & -0.53 & 0.87 \\
Aminopeptidase & -0.01 & 0.51 & 0.56 & 0.14 & 1 \\
Acid protease & 0.16 & 0.16 & -0.11 & & \\
\hline
\end{tabular}

Values at the top for each category denote the correlation coefficients; values at the bottom denote the $p$-value of the correlation.

\subsection{Bacterial Community of ML Silage}

3.5.1. The Dynamic Variation and Alpha Diversity of the Bacterial Community

The dynamic variation of the bacterial community was illustrated by principal component analysis (Figure 2). The results of the principal coordinate analysis was based on UniFrac (unweighted) distances. In the CK, the bacterial community showed the clearest distinctions when the ensiling time was prolonged. Moreover, after 7 days of ensiling, it was obvious that the silages treated with CA were separate from the CK, which suggested that the microbial community changed during the ensiling process. The distinctiveness of the bacterial communities among all treatments might account for the better fermentation that occurred in the ML silages treated with CA.

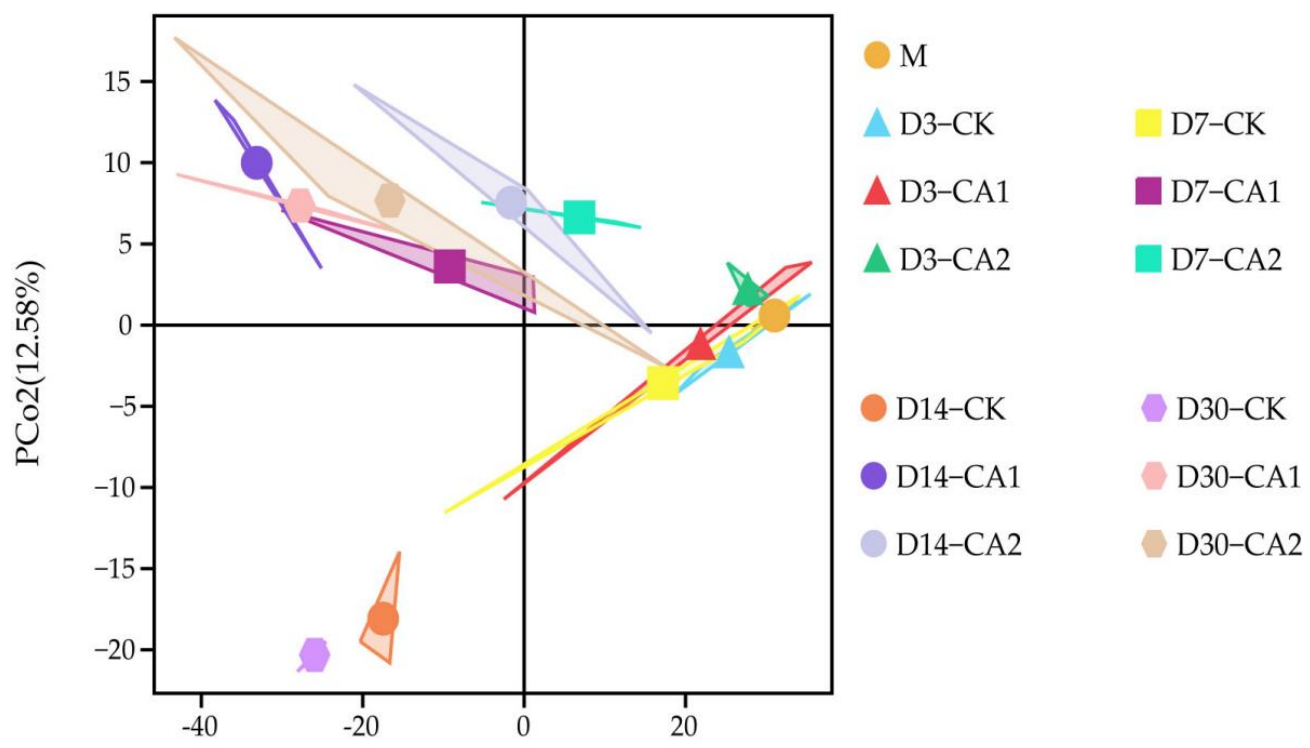

\section{PCo1 $(80.53 \%)$}

Figure 2. Principal component analysis of the bacterial community for mulberry leaf silages (M, pre-ensiled material; CK, the control; CA1, 1\% citric acid; CA2, 2\% citric acid; D3, 3 days of ensiling; D7, 7 days of ensiling; D14, 14 days of ensiling; D30, 30 days of ensiling). 
The alpha diversity of the bacterial community in ML silage is shown in Table 5 . The coverage values of all samples were approximately 0.99 , which indicated that most of the bacterial community was captured by the adequately large sequencing data. The Sobs, Ace and Chao1 indices decreased, but the Simpson index increased with a longer ensiling time, which indicated that the bacterial richness of ML silage decreased and dominant bacterial community richness increased. Compared with the $\mathrm{CK}$, the silage treated with CA generally showed a lower Shannon index at the same stage of ensiling, which indicated that CA decreased the diversity of the bacterial community of ML silage.

Table 5. Alpha diversity of the bacterial community for mulberry leaf silages.

\begin{tabular}{|c|c|c|c|c|c|}
\hline \multirow{2}{*}{ Items } & \multirow{2}{*}{ Treatments } & \multicolumn{4}{|c|}{ Ensiling Days } \\
\hline & & 3 & 7 & 14 & 30 \\
\hline \multirow{3}{*}{ Sobs } & CK & 1605 & 1339 & 1384 & 1373 \\
\hline & CA1 & 1477 & 1402 & 1102 & 1305 \\
\hline & CA2 & 1376 & 1499 & 1301 & 1337 \\
\hline \multirow{3}{*}{ Ace } & CK & 2512 & 2242 & 2263 & 2151 \\
\hline & CA1 & 2384 & 2348 & 1951 & 2097 \\
\hline & CA2 & 2159 & 2417 & 2152 & 2241 \\
\hline \multirow{3}{*}{ Chao1 } & CK & 2483 & 2268 & 2204 & 2115 \\
\hline & CA1 & 2308 & 2294 & 1964 & 2082 \\
\hline & CA2 & 2095 & 2453 & 2160 & 2168 \\
\hline \multirow{3}{*}{ Shannon } & CK & 3.00 & 3.18 & 5.02 & 5.22 \\
\hline & CA1 & 2.97 & 4.32 & 4.36 & 4.62 \\
\hline & CA2 & 2.62 & 3.59 & 3.68 & 4.13 \\
\hline \multirow{3}{*}{ Simpson } & CK & 0.50 & 0.56 & 0.89 & 0.93 \\
\hline & CA1 & 0.51 & 0.79 & 0.86 & 0.86 \\
\hline & CA2 & 0.45 & 0.66 & 0.71 & 0.76 \\
\hline \multirow{3}{*}{ Coverage } & $\mathrm{CK}$ & 0.99 & 0.99 & 0.99 & 0.99 \\
\hline & CA1 & 0.99 & 0.99 & 0.99 & 0.99 \\
\hline & CA2 & 0.99 & 0.99 & 0.99 & 0.99 \\
\hline
\end{tabular}

CK, the control; CA1, $1 \%$ citric acid; $\mathrm{CA} 2,2 \%$ citric acid.

3.5.2. The Changes in the Dynamics of Relative Abundance among Bacterial Communities

The changes in the dynamics of relative abundance among bacterial communities by phylum are shown in Figure 3. The relative abundance of Proteobacteria, Firmicutes and Bacteroidetes (up to $69 \%, 11 \%$ and $10 \%$, respectively) indicated that they were the dominant phylum in pre-ensiled ML; similar results were observed by Liu et al. [20]. With the prolonged ensiling time, the abundance of Proteobacteria and Bacteroidetes gradually decreased. After 30 days of ensiling, Firmicutes became the most abundant phylum in ML silages treated with CA, and Proteobacteria was still the most abundant phylum in the CK. Compared with the CK, the ML silages treated with CA showed a greater Firmicutes abundance but lower Proteobacteria abundance during all the stages of ensiling. Proteobacteria decreased in the silages treated with CA, which might be because the CA could enhance the permeability of the outer membrane of Gram-negative bacteria and inhibit the growth of Proteobacteria [33].

The dynamics of relative abundance among bacterial communities by genus are shown in Figure 4 . The relative abundance of bacterial communities was very low in the pre-ensiled ML. Methylobacterium (4.01\%) and Sphingomonas (1.03\%) were the dominant genera in pre-ensiled $\mathrm{ML}$, which was consistent with the results for pre-ensiled alfalfa reported by $\mathrm{Ni}$ et al. [34]. After 30 days of ensiling, Lactobacillus (24.9\%), Kosakonia (9.67\%), Enterobacter (8.96\%), Methylobacterium $(8.89 \%)$ and Enterococcus (6.26\%) were dominant in the CK, whereas Lactobacillus was the only dominant genus in the silages treated with CA. Lactobacillus is usually the dominant genus in silage due to its more active and rapid growth when the environmental $\mathrm{pH}$ declines. Some Lactobacillus species are usually screened as inoculants due to their rapid growth, which enhances the fermentation quality, such as Lactobacillus plantarum and Lactobacillus casei $[17,26]$. The relative abundance of Lactobacillus increased from 0.4 to $24.9,60.7$ and $47.3 \%$ in the CK and the silages treated with $1 \%$ CA and $2 \%$ CA after 30 days of ensiling, respectively. In the 
same fermentation period, the silages treated with CA showed a higher Lactobacillus abundance, which was consistent with the higher accumulation of lactic acid content (Figure 1). Moreover, Lactobacillus abundance decreased in the silages treated with $1 \%$ CA after 14 days of ensiling, which might be due to the rapid depletion of fermentation substrates, which could not support the growth of Lactobacillus. The rapid depletion of fermentation substrate abundance might be responsible for the conversion of lactic acid to acetic acid in the silages treated with $1 \% \mathrm{CA}$ because lactic acid becomes an alternative fermentation substrate for Lactobacillus. Similarly, Yan et al. [15] observed that relatively high Lactobacillus abundance corresponds to an elevation in acetic acid and a reduction in lactic acid. This conversion might be because different species of Lactobacillus have different metabolic patterns and functions. Similar to Lactobacillus, Enterococcus are desirable bacteria in the initial fermentation process, with the function of producing lactic acid to create a weak acid environment, which contributes to Lactobacillus fermentation. In the silages treated with CA, the relative abundance of Enterococcus decreased (Figure 5), which might be due to its low tolerance to the acidic environment caused by CA $[17,23]$.

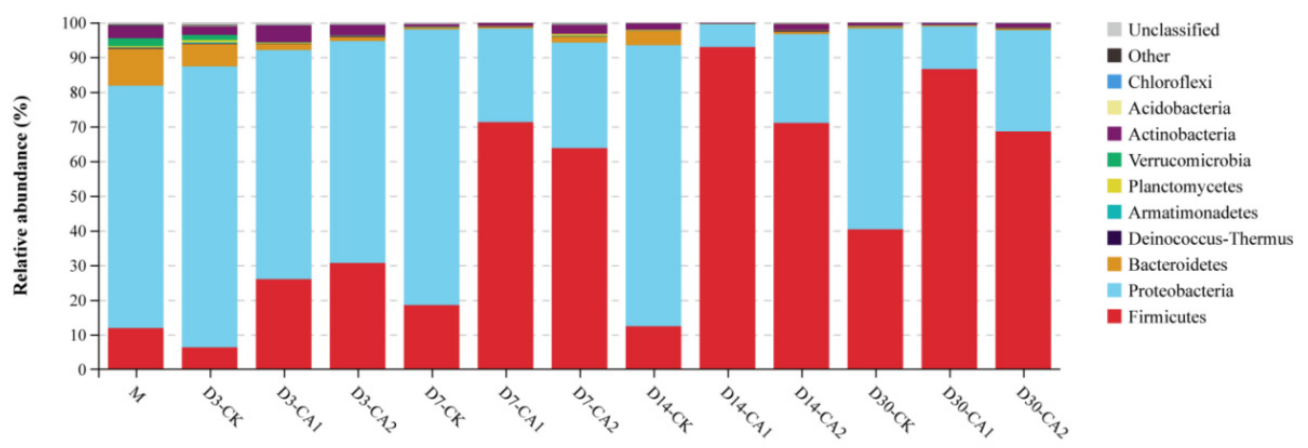

Figure 3. Bacterial community and relative abundance by phylum for mulberry leaf silages (M, pre-ensiled material; CK, the control; CA1, 1\% citric acid; CA2, 2\% citric acid; D3, 3 days of ensiling; D7, 7 days of ensiling; D14, 14 days of ensiling; D30, 30 days of ensiling).

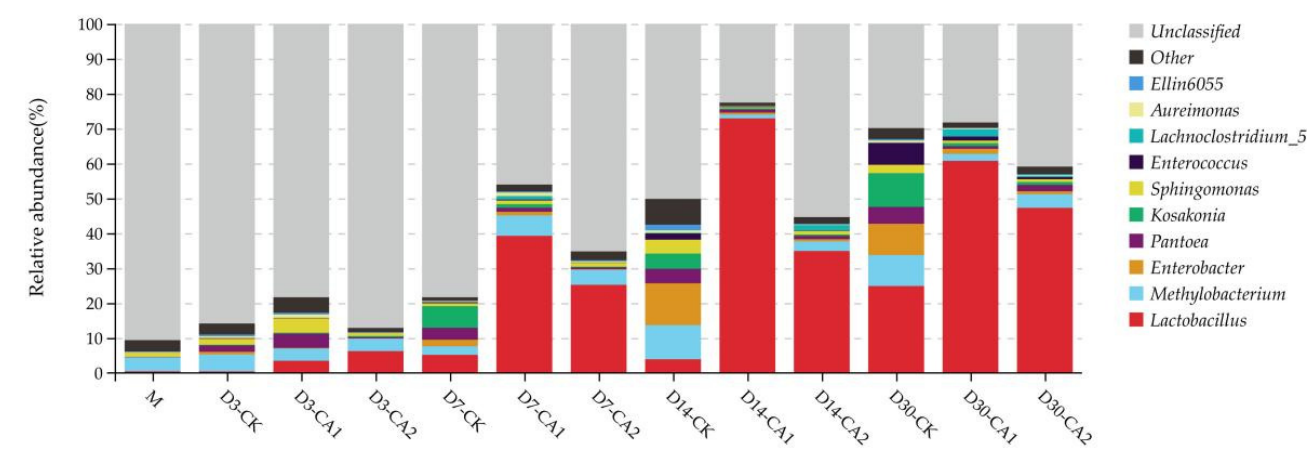

Figure 4. Bacterial community and relative abundance by genus for mulberry leaf silages (M, pre-ensiled material; CK, the control; CA1, 1\% citric acid; CA2, 2\% citric acid; D3, 3 days of ensiling; D7, 7 days of ensiling; D14, 14 days of ensiling; D30, 30 days of ensiling).

It is known that Enterobacter is an undesirable facultative anaerobe in the fermentation process, being the principal competitor of the lactic acid bacteria for water-soluble carbohydrates under anaerobic conditions; its principal fermentation product is acetic acid [26]. Yang et al. [35] reported that Enterobacter was positively correlated with $\mathrm{pH}$ and negatively correlated with lactic acid. The high relative abundance of Enterobacter could explain the relatively high $\mathrm{pH}$ (5.99) and acetic acid content $(11.0 \mathrm{~g} / \mathrm{kg} \mathrm{DM})$ in CK after 30 days of ensiling. Moreover, Enterobacter can deaminate and decarboxylate amino acids, thereby enhancing ammonia-N production [36]. The relative abundance of Enterobacter decreased from 8.96 to $0.83 \%$ with the addition of CA after 30 days of ensiling in this study (Figure 5), which might account for the lower acetic acid and ammonia-N content in the silages treated with CA. Methylobacterium are facultative methylotrophic bacteria and are commonly symbiotic with plants. The relative abundance of 
Methylobacterium decreased from 9.78 to $1.12 \%$ and 8.89 to $2.00 \%$ in the silages treated with CA after 14 days and 30 days of ensiling, respectively, because it is strictly aerobic and neutrophilic (Figure 5) [37]. Methylobacterium are considered to be undesirable bacteria in silage because it positively correlates with levels of ammonia-N and negatively correlates with lactic acid [38,39]. The roles of Sphingomonas, Pantoea and Kosakonia in silage are still unclear. Fitzgerald et al. [40] observed that Sphingomonas is involved in nitrification under low dissolved oxygen conditions, which might resist the production of ammonia-N. The relative abundance of Sphingomonas decreased from 2.38 to $0.72 \%$ in the silages treated with CA after 30 days of ensiling. Ogunade et al. [39] speculated that Pantoea could preserve protein through their negative correlation with ammonia-N content. However, Li et al. [41] inferred that Pantoea might compete for the fermentation substrate with lactic acid bacteria and cause an accumulation of butyric acid in silage because Pantoea is separate from the Enterobacter genus. Furthermore, Guan et al. [42] reported that Pantoea was more active in high-moisture environments and positively correlated with butyric acid. However, no butyric acid was detected in the current study, which might be due to the low relative abundance of Pantoea $(0.08 \%)$ in pre-ensiled ML. Similar to Pantoea, Kosakonia was separated from the Enterobacter genus. He et al. [43] reported that Kosakonia might reduce the ammonia- $\mathrm{N}$ content in silage due to its potential nitrogen fixing. The relative abundance of Pantoea and Kosakonia showed a similarly increasing trend in the CK during ensiling and was lower in the silages treated with CA in the current study. The relative abundance of Pantoea and Kosakonia decreased from 4.82 to $0.75 \%$ and 9.68 to $0.86 \%$ after 30 days of ensiling, respectively (Figure 5). The potential capacity of Pantoea, Kosakonia and Sphingomonas to reduce ammonia-N might explain the relatively low ammonia-N in the CK after 30 days of ensiling (Table 2). However, the conventional functions of Pantoea and Kosakonia in silage are complicated; therefore, more research should be conducted to evaluate their function. Moreover, Roseomonas (Gram-negative bacteria) can split urea and assimilate arabinose and glucose, suggesting that it might compete for water-soluble carbohydrates with lactic acid bacteria and promote the production of ammonia-N [44]. The relative abundance of Roseomonas in the silages treated with CA decreased from 0.05 to $0.03 \%$, from 0.10 to $0.03 \%$, from 0.66 to $0.01 \%$ and from 0.20 to $0.03 \%$ after $3,7,14$ and 30 days of ensiling in the current study, respectively.

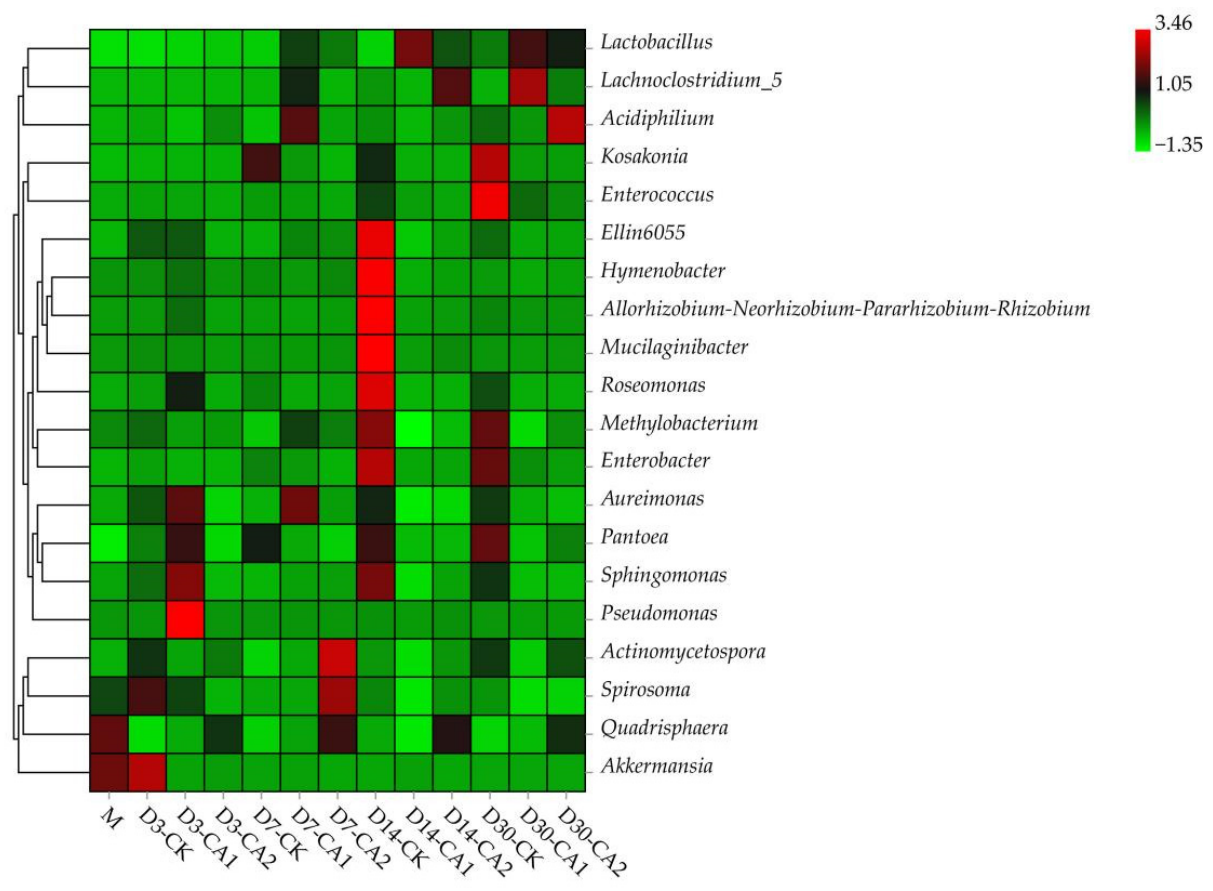

Figure 5. Heatmap of prominent bacterial genera (20 most abundant genera) for mulberry leaf silages (M, pre-ensiled material; CK, the control; CA1, 1\% citric acid; CA2, 2\% citric acid; D3, 3 days of ensiling; D7, 7 days of ensiling; D14, 14 days of ensiling; D30, 30 days of ensiling). 


\subsubsection{S rDNA Gene-Predicted Functional Profiles}

The 16S rDNA gene-predicted functional profiles are shown in Figure 6. CA inhibited the metabolism of energy, carbohydrate, folding, sorting and degradation, and membrane transport, which might be attributed to $\mathrm{CA}$ decreasing the $\mathrm{pH}$ value and inhibiting microbial activities directly. Moreover, CA inhibited the amino acid metabolism. Thus, the decrease in ammonia-N in the silages treated with CA might be because CA reduced the amino acid metabolism of Enterobacter, consistent with the decrease in Enterobacter abundance. All conversions of the abovementioned bacteria communities suggest that CA could enhance lactic acid bacteria fermentation by inhibiting the undesirable microorganisms in ML silage. The reduction in undesirable microorganisms and the increase in lactic acid bacteria might account for the lower $\mathrm{pH}$, the increased $\mathrm{DM}$ recovery and the reduction in ammonia-N content in the silage treated with CA. Overall, CA had a positive effect on the fermentation quality and silage quality of ML.

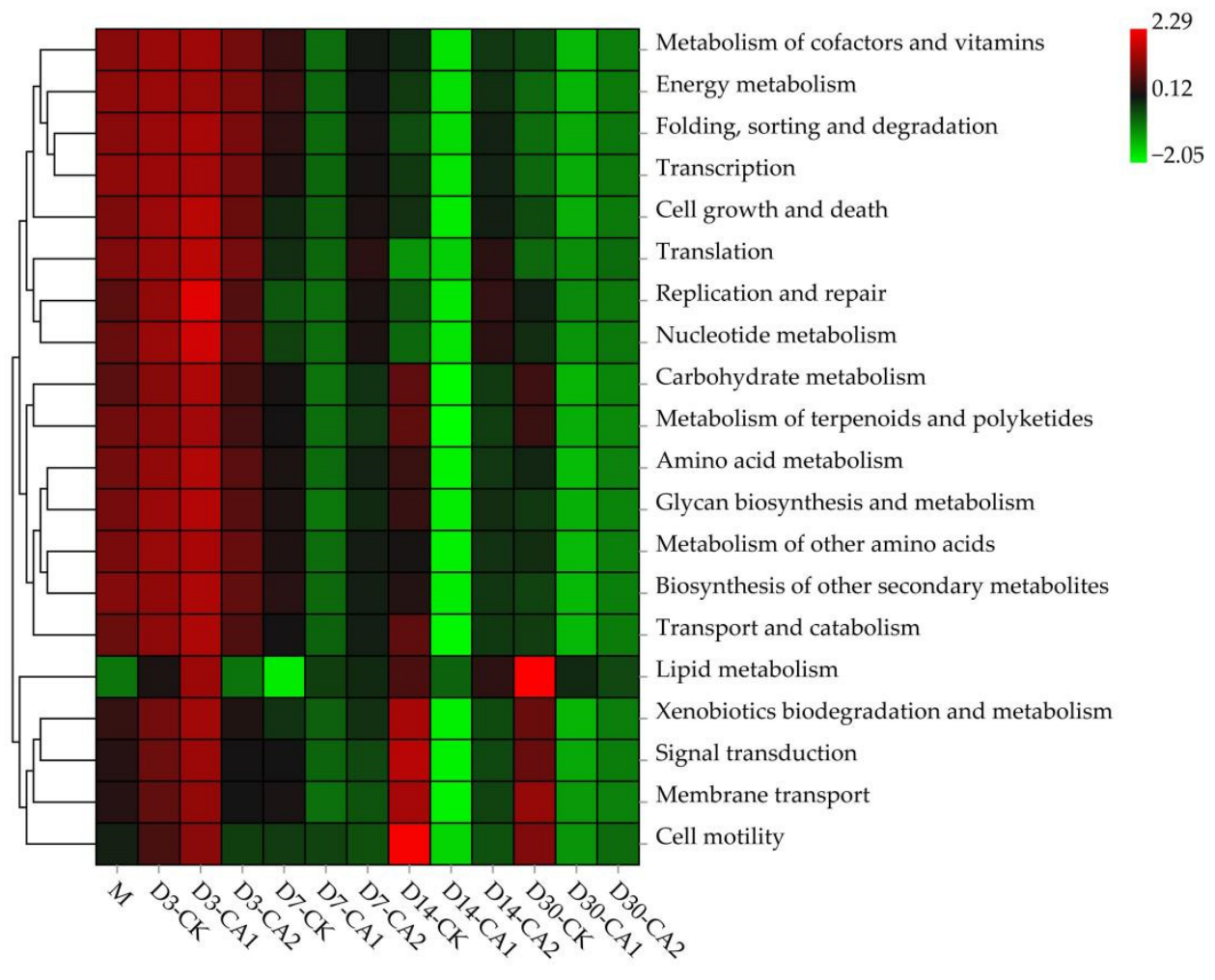

Figure 6. Heatmap of $16 \mathrm{~S}$ rDNA gene-predicted functional profiles obtained with PICRUSt2 (M, pre-ensiled material; $\mathrm{CK}$, the control; CA1, $1 \%$ citric acid; CA2, 2\% citric acid; D3, 3 days of ensiling; D7, 7 days of ensiling; D14, 14 days of ensiling; D30, 30 days of ensiling).

\section{Conclusions}

The study reveal that CA was useful for improving the fermentation quality and nutrition of ML silage. The content of acetic acid, non-protein nitrogen and ammonia-N, and coliform bacteria counts decreased in the silage treated with CA. The abundance of Enterobacter, Methylobacterium, Sphingomonas, Pantoea, Kosakonia and Roseomonas decreased, whereas Lactobacillus abundance increased when CA was added. Thus, the addition of CA could effectively preserve the quality of ML silage, and 2\% CA was the most effective.

Author Contributions: Conceptualization, D.C. and Q.Z.; methodology, W.Z.; software, D.C.; validation, D.C.; formal analysis, D.C.; investigation, X.G.; resources, X.G.; data curation, M.Z.; writingoriginal draft preparation, D.C. and W.Z.; writing-review and editing, D.C. and Q.Z.; supervision, Q.Z.; project administration, X.C. All authors have read and agreed to the published version of the manuscript. 
Funding: This work was financially supported by Guangzhou Forestry Science and Technology Innovation Commission (Grant No. 2018KJCX001, 2019KJCX001) and the National Natural Science Foundation of China Project (Grant No. 31771345).

Institutional Review Board Statement: Not applicable.

Informed Consent Statement: Not applicable.

Data Availability Statement: The sequences were deposited into the NCBI Sequence Read Archive (SRA) database, and the accession number is PRJNA725072.

Acknowledgments: In this section, you can acknowledge any support given which is not covered by the author contribution or funding sections. This may include administrative and technical support, or donations in kind (e.g., materials used for experiments).

Conflicts of Interest: The authors declare no conflict of interest.

\section{References}

1. Brief Introduction of Cocoon Silk Industry Operation in China. Available online: http://www.mofcom.gov.cn/article/ tongjiziliao/sjtj/jsc/201904/20190402852178.shtml (accessed on 12 April 2019).

2. Wang, Y.; Chen, X.; Wang, C.; He, L.; Zhou, W.; Yang, F.; Qing, Z. The bacterial community and fermentation quality of mulberry (Morus alba) leaf silage with or without Lactobacillus casei and sucrose. Bioresour. Technol. 2019, 293, 122059. [CrossRef]

3. Singh, B.; Makkar, H. The potential of mulberry foliage as feed supplement in India. Fao Anim. Prod. Health Pap. $2002,1,139-156$.

4. Ouyang, J.; Wang, M.; Hou, Q.; Feng, D.; Pi, Y.; Zhao, W. Effects of Dietary Mulberry Leaf Powder in Concentrate on the Rumen Fermentation and Ruminal Epithelium in Fattening Hu Sheep. Animals 2019, 9, 218. [CrossRef]

5. Król, E.; Jeszka-Skowron, M.; Krejpcio, Z.; Flaczyk, E.; Wójciak, R.W. The Effects of Supplementary Mulberry Leaf (Morus alba) Extracts on the Trace Element Status (Fe, $\mathrm{Zn}$ and $\mathrm{Cu}$ ) in Relation to Diabetes Management and Antioxidant Indices in Diabetic Rats. Biol. Trace Element Res. 2016, 174, 158-165. [CrossRef] [PubMed]

6. Park, E.; Lee, S.-M.; Lee, J.E.; Kim, J.-H. Anti-inflammatory activity of mulberry leaf extract through inhibition of NF-kB. J. Funct. Foods 2013, 5, 178-186. [CrossRef]

7. He, L.; Chen, N.; Lv, H.; Wang, C.; Zhou, W.; Chen, X.; Zhang, Q. Gallic acid influencing fermentation quality, nitrogen distribution and bacterial community of high-moisture mulberry leaves and stylo silage. Bioresour. Technol. 2020, 295, 122255. [CrossRef]

8. He, L.; Wang, C.; Xing, Y.; Zhou, W.; Pian, R.; Yang, F.; Chen, X.; Zhang, Q. Dynamics of proteolysis, protease activity and bacterial community of Neolamarckia cadamba leaves silage and the effects of formic acid and Lactobacillus farciminis. Bioresour. Technol. 2019, 294, 122127. [CrossRef]

9. Nozawa, S.R.; Rigoli, I.C.; Thedei, G., Jr.; Rossi, A. Mind the buffering capacity of citric acid. Fungal Genet. Rep. 1995, $42,56$. [CrossRef]

10. Ni, K.; Wang, F.; Zhu, B.; Yang, J.; Zhou, G.; Pan, Y.; Tao, Y.; Zhong, J. Effects of lactic acid bacteria and molasses additives on the microbial community and fermentation quality of soybean silage. Bioresour. Technol. 2017, 238, 706-715. [CrossRef]

11. Soccol, C.R.; Luciana, P.S.V.; Rodrigues, C.; Pandey, A. New perspectives for citric acid production and application. Food Technol. Biotech. 2006, 44, 141-149. [CrossRef]

12. Muck, R. Factors Influencing Silage Quality and Their Implications for Management. J. Dairy Sci. 1988, 71, 2992-3002. [CrossRef]

13. Lv, H.; Pian, R.; Xing, Y.; Zhou, W.; Yang, F.; Chen, X.; Zhang, Q. Effects of citric acid on fermentation characteristics and bacterial diversity of Amomum villosum silage. Bioresour. Technol. 2020, 307, 123290. [CrossRef]

14. Ke, W.; Ding, W.; Xu, D.; Ding, L.; Zhang, P.; Li, F.; Guo, X. Effects of addition of malic or citric acids on fermentation quality and chemical characteristics of alfalfa silage. J. Dairy Sci. 2017, 100, 8958-8966. [CrossRef]

15. Yan, Y.; Li, X.; Guan, H.; Huang, L.; Ma, X.; Peng, Y.; Li, Z.; Nie, G.; Zhou, J.; Yang, W.; et al. Microbial community and fermentation characteristic of Italian ryegrass silage prepared with corn stover and lactic acid bacteria. Bioresour. Technol. 2019, 279, 166-173. [CrossRef]

16. Broderick, G.; Kang, J. Automated Simultaneous Determination of Ammonia and Total Amino Acids in Ruminal Fluid and In Vitro Media. J. Dairy Sci. 1980, 63, 64-75. [CrossRef]

17. Zhang, Q.; Yu, Z.; Wang, X.; Tian, J. Effects of inoculants and environmental temperature on fermentation quality and bacterial diversity of alfalfa silage. Anim. Sci. J. 2018, 89, 1085-1092. [CrossRef] [PubMed]

18. Guo, X.; Zhou, H.; Yu, Z.; Zhang, Y. Changes in the distribution of nitrogen and plant enzymatic activity during ensilage of lucerne treated with different additives. Grass Forage Sci. 2007, 62, 35-43. [CrossRef]

19. Zhang, Y.C.; Li, D.X.; Wang, X.K.; Lin, Y.L.; Zhang, Q.; Chen, X.Y.; Yang, F.Y. Fermentation dynamics and diversity of bacterial community in four typical woody forages. Ann. Microbiol. 2019, 69, 233-240. [CrossRef]

20. Liu, B.; Huan, H.; Gu, H.; Xu, N.; Shen, Q.; Ding, C. Dynamics of a microbial community during ensiling and upon aerobic exposure in lactic acid bacteria inoculation-treated and untreated barley silages. Bioresour. Technol. 2019, 273, 212-219. [CrossRef] 
21. He, L.; Lv, H.; Chen, N.; Wang, C.; Zhou, W.; Chen, X.; Zhang, Q. Improving fermentation, protein preservation and antioxidant activity of Moringa oleifera leaves silage with gallic acid and tannin acid. Bioresour. Technol. 2020, 297, 122390. [CrossRef] [PubMed]

22. Nelson, C.J.; Moser, L.E. Plant Factors Affecting Forage Quality. In Forage Quality, Evaluation, and Utilization; Acsess Publication: Madison, WI, USA, 1994; pp. 115-154. [CrossRef]

23. Cai, Y.; Benno, Y.; Ogawa, M.; Ohmomo, S.; Kumai, S.; Nakase, T. Influence of Lactobacillus spp. from an Inoculant and of Weissella and Leuconostoc spp. from Forage Crops on Silage Fermentation. Appl. Environ. Microbiol. 1998, 64, 2982-2987. [CrossRef] [PubMed]

24. Borreani, G.; Tabacco, E.; Schmidt, R.; Holmes, B.; Muck, R. Silage review: Factors affecting dry matter and quality losses in silages. J. Dairy Sci. 2018, 101, 3952-3979. [CrossRef] [PubMed]

25. Trabi, E.B.; Yuan, X.; Li, J.; Dong, Z.; Shah, A.A.; Shao, T. Effect of Glucose and Lactic Acid Bacteria on the Fermentation Quality, Chemical Compositions and in vitro Digestibility of Mulberry (Morus Alba) Leaf Silage. Pak. J. Zool. 2017, 49. [CrossRef]

26. Ranjit, N.; Kung, L. The Effect of Lactobacillus buchneri, Lactobacillus plantarum, or a Chemical Preservative on the Fermentation and Aerobic Stability of Corn Silage. J. Dairy Sci. 2000, 83, 526-535. [CrossRef]

27. Muck, R.; Nadeau, E.; McAllister, T.A.; Contreras-Govea, F.; Santos, M.; Kung, L. Silage review: Recent advances and future uses of silage additives. J. Dairy Sci. 2018, 101, 3980-4000. [CrossRef]

28. Mohan, A.; Pohlman, F. Role of organic acids and peroxyacetic acid as antimicrobial intervention for controlling Escherichia coli O157:H7 on beef trimmings. LWT Food Sci. Technol. 2016, 65, 868-873. [CrossRef]

29. Omidiran, M.O.; Baiyewu, R.A.; Ademola, I.T.; Fakorede, O.C.; Toyinbo, E.O.; Adekunle, E.A. Phytochemical Analysis, Nutritional Composition and Antimicrobial Activities of White Mulberry (Morus alba). Pak. J. Nutr. 2012, 11, 456-460. [CrossRef]

30. Mcdonald, P.; Henderson, A.R.; Heron, S.J.E. The Biochemistry of Silage; Chalcombe Publication: Marlow Bucks, UK, 1991.

31. Ke, W.; Ding, W.; Xu, D.; Shah, M.N.; Zhang, P.; Guo, X. Influences of addition of malic acid or citric acid, Lactobacillus plantarum and their mixtures on fermentation quality, proteolysis and fatty acid composition of ensiled alfalfa. Arch. Anim. Nutr. 2018, 72, 492-502. [CrossRef]

32. Yuan, X.; Wen, A.; Desta, S.T.; Dong, Z.; Shao, T. Effects of four short-chain fatty acids or salts on the dynamics of nitrogen transformations and intrinsic protease activity of alfalfa silage. J. Sci. Food Agric. 2017, 97, 2759-2766. [CrossRef]

33. Helander, I.M.; Mattila-Sandholm, T. Fluorometric assessment of Gram-negative bacterial permeabilization. J. Appl. Microbiol. 2000, 88, 213-219. [CrossRef]

34. Ni, K.; Minh, T.T.T.; Tu, T.T.M.; Tsuruta, T.; Pang, H.; Nishino, N. Comparative microbiota assessment of wilted Italian ryegrass, whole crop corn, and wilted alfalfa silage using denaturing gradient gel electrophoresis and next-generation sequencing. Appl. Microbiol. Biotechnol. 2017, 101, 1385-1394. [CrossRef]

35. Yang, L.; Yuan, X.; Li, J.; Dong, Z.; Shao, T. Dynamics of microbial community and fermentation quality during ensiling of sterile and nonsterile alfalfa with or without Lactobacillus plantarum inoculant. Bioresour. Technol. 2018, 275, 280-287. [CrossRef] [PubMed]

36. Queiroz, O.; Ogunade, I.; Weinberg, Z.; Adesogan, A. Silage review: Foodborne pathogens in silage and their mitigation by silage additives. J. Dairy Sci. 2018, 101, 4132-4142. [CrossRef] [PubMed]

37. Knief, C.; Delmotte, N.; Chaffron, S.; Stark, M.; Innerebner, G.; Wassmann, R.; von Mering, C.; A Vorholt, J. Metaproteogenomic analysis of microbial communities in the phyllosphere and rhizosphere of rice. ISME J. 2011, 6, 1378-1390. [CrossRef] [PubMed]

38. Guo, L.; Yao, D.; Li, D.; Lin, Y.; Bureenok, S.; Ni, K.; Yang, F. Effects of Lactic Acid Bacteria Isolated from Rumen Fluid and Feces of Dairy Cows on Fermentation Quality, Microbial Community, and in vitro Digestibility of Alfalfa Silage. Front. Microbiol. 2020, 10, 2998. [CrossRef]

39. Ogunade, I.; Jiang, Y.; Cervantes, A.P.; Kim, D.; de Oliveira, A.S.; Vyas, D.; Weinberg, Z.; Jeong, K.; Adesogan, A. Bacterial diversity and composition of alfalfa silage as analyzed by Illumina MiSeq sequencing: Effects of Escherichia coli O157:H7 and silage additives. J. Dairy Sci. 2018, 101, 2048-2059. [CrossRef] [PubMed]

40. Fitzgerald, C.M.; Camejo, P.; Oshlag, J.Z.; Noguera, D.R. Ammonia-oxidizing microbial communities in reactors with efficient nitrification at low-dissolved oxygen. Water Res. 2015, 70, 38-51. [CrossRef]

41. Li, L.; Yuan, Z.; Sun, Y.; Kong, X.; Dong, P.; Zhang, J. A reused method for molasses-processed wastewater: Effect on silage quality and anaerobic digestion performance of Pennisetum purpereum. Bioresour. Technol. 2017, 241, 1003-1011. [CrossRef]

42. Guan, H.; Yan, Y.; Li, X.; Li, X.; Shuai, Y.; Feng, G.; Ran, Q.; Cai, Y.; Li, Y.; Zhang, X. Microbial communities and natural fermentation of corn silages prepared with farm bunker-silo in Southwest China. Bioresour. Technol. 2018, 265, 282-290. [CrossRef]

43. He, L.; Wang, C.; Xing, Y.; Zhou, W.; Pian, R.; Chen, X.; Zhang, Q. Ensiling characteristics, proteolysis and bacterial community of high-moisture corn stalk and stylo silage prepared with Bauhinia variegate flower. Bioresour. Technol. 2020, 296, 122336. [CrossRef]

44. Han, X.Y.; Pham, A.S.; Tarrand, J.J.; Rolston, K.V.; Helsel, L.O.; Levett, P.N. Bacteriologic Characterization of 36 Strains of Roseomonas Species and Proposal of Roseomonas mucosasp nov and Roseomonas gilardii subsp rosea subsp nov. Am. J. Clin. Pathol. 2003, 120, 256-264. [CrossRef] [PubMed] 